\author{
ANNA BARCZAK \\ EWA KOWALEWSKA \\ Uniwersytet Szczeciński
}

\title{
Źródła finansowania zadań z zakresu ochrony środowiska w Polsce - przegląd stosowanych rozwiązań
}

\section{Financing Sources of Tasks in the Field of Environmental Protection in Poland - an Overview of Applied Solutions}

Streszczenie. W ciągu ostatnich dziesięciu lat w Polsce odnotować należy znaczący rozwój inwestycji na rzecz ochrony środowiska. Celem niniejszego opracowania jest przedstawienie instrumentów finansowych stanowiących źródła finansowania zadań w sferze ochrony środowiska. Zwrócono uwagę na ich szczególną rolę. Podkreślono, iż bez udziału tych wszystkich instrumentów niemożliwe byłoby osiągnięcie zakładanych w Polityce Ekologicznej Państwa oraz samorządowych programach ochrony środowiska, zamierzeń i priorytetów ekologicznych. Niniejsze opracowanie jest kompleksową analizą materiału normatywnego oraz poglądów prezentowanych w literaturze prawa finansowego i prawa ochrony środowiska.

Słowa kluczowe: finansowanie zadań z zakresu ochrony środowiska; kredyty i pożyczki; fundusze ochrony środowiska; środki unijne; wsparcie finansowe. 


\begin{abstract}
A significant development of investments to protect environment has been noticed in the past ten years in Poland. The purpose of this paper is to present financial instruments which are the financing sources of the tasks in the field of environmental protection. It has been noticed their special role. It has also been emphasized that without the participation of all those instruments would be impossible to achieve environmental plans and priorities, projected in the National Environmental Policy and local environmental programs. This study is a comprehensive analysis of the normative material and ideas presented in the literature of financial and environmental law.
\end{abstract}

Keywords: financing in the field of environmental protection; credits and loans; environmental protection funds; EU funds; financial support.

\title{
1. Wstęp
}

System finansowy to obowiązujące zasady i funkcjonujące instytucje finansowe, stworzone przez obowiązujące w danym państwie i w danym czasie prawo finansowe. System finansowy w gospodarce oznacza natomiast mechanizm, dzięki któremu świadczy się usługi pozwalające na krążenie siły nabywczej w gospodarce. Z kolei system finansowy ochrony środowiska to zbiór zasad i przepisów określających sposoby, tryb gromadzenia i redystrybucji środków pieniężnych na ten cel ${ }^{1}$.

W ciągu ostatniego dziesięciolecia w Polsce odnotować można rozwój inwestycji na rzecz ochrony środowiska. Sprzyjają temu stosowane przez państwo narzędzia polityki proekologicznej, do których zalicza się instrumenty o charakterze prawnym, finansowym i organizacyjnym. Jednocześnie, co należy zaznaczyć, obecnie za rozwój działalności z zakresu ochrony środowiska odpowiedzialna jest nie tylko administracja publiczna (centralna i samorządowa), ale także sektor prywatny (w tym podmioty korzystające ze środowiska i oddziaływujące na nie).

Wewnętrzny rynek polski, tak jak europejski, dostrzega problemy ochrony środowiska i stawia je jako jeden z niezbędnych elementów roz-

1 Materiały źródłowe na stronie internetowej http://www.proekologia.pl (dostęp: 28 października 2013 r.). 
woju, budowania konkurencyjności i wizerunku podmiotów na nim funkcjonujących.

Korzystanie ze środowiska naturalnego i jego zasobów generuje konieczność ponoszenia nakładów inwestycyjnych, rozumianych jako nakłady finansowe lub rzeczowe. Ich celem jest stworzenie nowych środków trwałych lub ulepszenie istniejących obiektów majątku trwałego ${ }^{2}$. Nakłady inwestycyjne dzieli się na: nakłady na środki trwałe i pozostałe nakłady.

Wśród źródeł finansowania zadań z zakresu ochrony środowiska wyróżnić należy środki: budżetowe, prywatne oraz zagraniczne. Środki budżetowe dzielą się na: środki centralne i samorządu terytorialnego. Do prywatnych zaliczyć należy natomiast: środki własne inwestorów, kredyty i pożyczki - w tym udzielane przez Bank Ochrony Środowiska S.A. (dalej: BOŚ), Bank Gospodarstwa Krajowego (BGK) oraz przez banki komercyjne - oraz fundusze ochrony środowiska ${ }^{3}$. Wśród środków zagranicznych wymienić należy przede wszystkim środki unijne oraz pozostałe środki zagraniczne.

Podział źródeł finansowania zadań z zakresu ochrony środowiska przedstawia Schemat 1.

2 Ochrona środowiska 2012. Informacje i opracowania statystyczne, Warszawa 2012, s. 401, http://www.stat.gov.pl (dostęp: 28 października 2013 r.).

3 Fundusze ochrony środowiska zaliczone zostały do środków prywatnych finansujących zadania z zakresu ochrony środowiska przede wszystkim z uwagi na źródło ich pochodzenia. Narodowy Fundusz Ochrony Środowiska i Gospodarki Wodnej oraz wojewódzkie fundusze ochrony środowiska i gospodarki wodnej nie są funduszami celowymi, są państwową osobą prawną w rozumieniu ustawodawstwa z zakresu prawa finansowego. Jednakże sam fakt posiadania tego statusu nie przesądza o charakterze środków, którymi fundusz dysponuje. Ponadto wysokość tych środków nie jest ustalona w ustawie budżetowej, zarówno ich pochodzenie, jak i kierunki ich przeznaczenia są wielowymiarowe. 
Schemat 1.

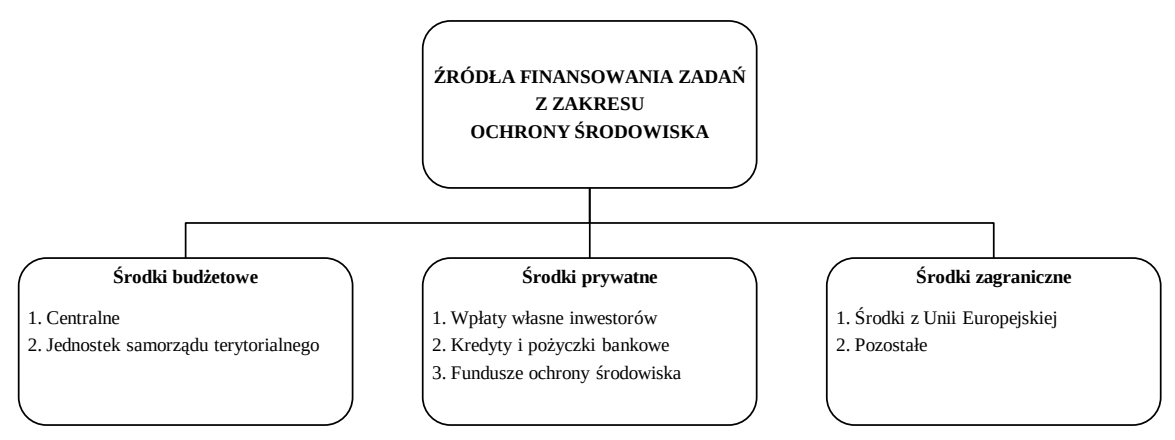

Źródło: opracowanie własne ${ }^{4}$.

Źródła finansowania zadań dotyczących ochrony środowiska można także podzielić na wewnętrzne i zewnętrzne. Zaproponowany podział jest pełny i wymusza w konsekwencji zwrócenie uwagi na siłę i znaczenie oddziaływania każdego ze wskazanych środków.

Podkreślenia wymaga to, że często zadania z zakresu ochrony środowiska finansowane są jednocześnie z dwóch lub więcej źródeł - np. z budżetu państwa i Narodowego Funduszu Ochrony Środowiska i Gospodarki Wodnej (dalej: NFOŚiGW).

\section{Rola środków budżetowych w finansowaniu ochrony środowiska}

System finansowania ochrony środowiska jest integralną częścią systemu finansowego państwa. Został on ukształtowany przed integracją Polski z Unią Europejską i oparty na odmiennej filozofii i źródłach prawa ${ }^{5}$.

Środki budżetowe należy rozumieć jako zasoby finansowe własne państwa, województw, powiatów i gmin. Wysokość środków budżeto-

4 Zaproponowany podział źródeł finansowania zadań z zakresu ochrony środowiska należy odróżnić od podziału środków na publiczne i prywatne. W tym przypadku wyróżniono środki budżetowe i prywatne oraz dodatkowo zagraniczne.

5 B. Poskrobko, J. Ejdys, System ochrony środowiska w Polsce, [w:] B. Kozłowska (red.), Instrumenty polityki ekologicznej, Łódź 2005, s. 100. 
wych państwa jest corocznie ustalana w ustawie budżetowej ${ }^{6}$. Wydatki na ochronę środowiska są rozproszone w różnych częściach i działach budżetu, w układzie ministerstw i urzędów centralnych, rezerw celowych, inwestycji centralnych finansowanych $\mathrm{z}$ dotacji celowych na zadania własne gmin i inne ${ }^{7}$.

Budżet państwa finansuje działalność ochrony środowiska także w sposób pośredni, udzielając subsydiów dla gmin. Te z kolei mogą otrzymane $\mathrm{w}$ ten sposób środki przeznaczyć na inwestycje w sferze ochrony środowiska. Ponadto pośrednio budżet państwa wpływa na ten rodzaj działalności również poprzez stosowanie ulg i zwolnień podatkowych wobec podmiotów prowadzących działalność gospodarczą oraz osób fizycznych, jeśli podejmują się realizacji zadań z zakresu ochrony środowiska.

Dotacje mogą być formą pomocy finansowej udzielanej podmiotom gospodarującym, które spełniają wymogi stawiane przez donatorów. Dotacje są udzielane nie na zasadach, wynikających z mechanizmów rynkowych, lecz na zasadach, które określa polityka i dokumenty rządowe. Za stosowaniem dotacji w polityce ochrony środowiska przemawiają :

- $\quad$ konieczność usunięcia istotnej presji na środowisko, mającej znaczące oddziaływanie na zdrowie ludzi i stan środowiska,

- $\quad$ dążenie do szybkiego usunięcia negatywnego oddziaływania na środowisko,

- potrzeba dotowania kosztownych inwestycji ochronnych, zagrożonych utratą miejsc pracy,

- $\quad$ konieczność finansowania ze środków publicznych inwestycji proochronnych o znaczeniu ogólnospołecznym.

\footnotetext{
Ustawa budżetowa na rok 2013 z dnia 25 stycznia 2013 r. (Dz.U., poz. 169 ze zm.). J. Wyzińska-Ludian, Źródła finansowania ekorozwoju, [w:] J. Zalewa (red.), Ekonomiczno-finansowe i prawne instrumenty ochrony środowiska naturalnego w Polsce, Lublin 2001, s. 53.

8 B. Poskrobko, J. Ejdys, Ekonomiczne i rynkowe mechanizmy polityki ekologicznej, [w:] B. Kozłowska (red.), Instrumenty polityki ekologicznej..., s. 73.
} 


\section{3. Środki prywatne jako źródło finansowania zadań z zakresu ochrony środowiska}

\section{1. Środki własne inwestorów}

Środki własne inwestorów, czyli przedsiębiorców lub osób fizycznych, to wydatki przeznaczone na realizację zadań związanych z ochroną środowiska. Ponoszone są one z reguły z dwóch źródeł: środków bieżących lub pożyczek i kredytów (w tym również kredytów preferencyjnych udzielanych m.in. przez BOŚ). Wydatki takie mogą być ponoszone także na zapewnienie funkcjonowania wdrożonych już w przedsiębiorstwie procesów, mających na celu ochronę środowiska bądź też związanych $\mathrm{z}$ zapewnieniem funkcjonowania zarządzania $\mathrm{w}$ zakresie ochrony środowiska.

Przedsiębiorcy w zakresie szeroko rozumianej działalności proekologicznej mogą ponosić także nakłady inwestycyjne. Są one finansowane ze specjalnie wydzielanych środków inwestycyjnych (środki bezzwrotne lub własne środki zwrotne, kredyty bankowe, pożyczki, wpływy z emisji papierów wartościowych, leasingu itp.).

\subsection{Fundusze ochrony środowiska}

W literaturze przedmiotu wskazano, że fundusze ochrony środowiska odgrywają główną rolę w finansowaniu inwestycji na rzecz ochrony środowiska ${ }^{10}$. Po przystąpieniu Polski do Unii Europejskiej podstawowym zadaniem funduszy ochrony środowiska stało się wspieranie sprawnego i efektywnego wykorzystania funduszy unijnych.

W obowiązującym ustawodawstwie brak jest legalnej definicji terminów: „fundusze ekologiczne”11, „fundusze środowiskowe”, „fundusze

\footnotetext{
9 B. Poskrobko, Zarzqdzanie środowiskiem, Warszawa 1999, s. 273.

10 Por. J. Ciechanowicz-McLean, Fundusze Ochrony Środowiska i Gospodarki Wodnej, [w:] J. Ciechanowicz-McLean (red.), Leksykon ochrony środowiska, Warszawa 2009, s. 33.

11 Tamże, s. 34.
} 
ochrony środowiska” ${ }^{2}$. Również doktryna nie wyjaśnia wymienionych pojęć, choć się nimi posługuje ${ }^{13}$. Terminem „fundusze ekologiczne” posługują się także różne instytucje ${ }^{14}$. Należy wskazać na brak konsekwencji w stosowaniu wskazanych terminów.

Na potrzeby niniejszego opracowania właściwe wydaje się przyjęcie terminu „fundusze ochrony środowiska” jako adekwatnego i jednocześnie nawiązującego do ogólnej terminologii przyjętej przez ustawodawcę.

Zgodnie z definicją fundusze ochrony środowiska stanowią opracowane i wdrożone w Polsce narzędzia gromadzenia i redystrybucji środków finansowych na realizację zadań publicznych z zakresu ochrony środowiska ${ }^{15}$.

Fundusze są specyficznym źródłem finansowania zadań ochrony środowiska. Zajmują się one pozyskiwaniem, ale także redystrybucją środków finansowych na przedsięwzięcia, których celem jest ochrona środowiska. W Polsce funkcjonują następujące fundusze ochrony środowiska:

1. Narodowy Fundusz Ochrony Środowiska i Gospodarki Wodnej,

2. Wojewódzkie fundusze ochrony środowiska i gospodarki wodnej,

3. Fundusz Leśny.

NFOŚiGW oraz wojewódzkie fundusze ochrony środowiska i gospodarki wodnej (dalej: WFOŚiGW) ${ }^{16}$ zostały utworzone na mocy ustawy z dnia 27 kwietnia 1989 r. o zmianie ustawy o ochronie i kształtowaniu

12 S. Urban, Finansowanie ochrony środowiska i gospodarki wodnej, [w:] M. Górski, M. Pchałek, W. Radecki, J. Jerzmański, M. Bar, S. Urban, J. Jendrośka, Prawo ochrony środowiska. Komentarz, Warszawa 2011, s. 1290.

13 Zob. B. Poskrobko, T. Poskrobko, Zarzqdzanie środowiskiem w Polsce, Warszawa 2012, s. 84; J. Wyzińska-Ludian, Źródła finansowania ekorozwoju..., s. 56.

14 Według Głównego Urzędu Statystycznego „przez fundusze ekologiczne można rozumieć fundusze tworzone $\mathrm{z}$ opłat między innymi za korzystanie ze środowiska i wprowadzanie w nim zmian, w tym za pobór i korzystanie z wód i wprowadzanie ścieków, opłat eksploatacyjnych i koncesyjnych wynikających z ustawy prawo geologiczne i górnicze, z kar za naruszenie wymagań w zakresie ochrony środowiska, wydobywanie kopalin bez wymaganej koncesji lub z rażącym naruszeniem jej warunków oraz innych wpływów”. Ochrona środowiska 2012, s. 44.

15 J. Jendrośka (red.), Leksykon prawa ochrony środowiska, Warszawa 2012, s. 44.

16 Zob. szerzej: Z. Bukowski, [w:] J. Ciechanowicz-McLean, Z. Bukowski, B. Rakoczy, Prawo ochrony środowiska. Komentarz, Warszawa 2008, s. 620-630; P. Smoleń, Fundusze ochrony środowiska i gospodarki wodnej, [w:] J. Stelmasiak (red.), Prawo ochrony środowiska, Warszawa 2009, s. 187-195. 
środowiska i ustawy - Prawo wodne ${ }^{17}$. Do 31 grudnia 2009 r. istniały także gminne fundusze ochrony środowiska i gospodarki wodnej oraz powiatowe fundusze ochrony środowiska i gospodarki wodnej. Jednakże z dniem 1 stycznia 2010 r. powiatowe oraz gminne fundusze ochrony środowiska i gospodarki wodnej uległy likwidacji, a ich środki włączono do źródeł dochodów budżetów gmin i powiatów.

Nowelizacja ustawy Prawo ochrony środowiska ${ }^{18}$ w 2009 r. ${ }^{19}$ wprowadziła regulację, zgodnie z którą wpływy z tytułu opłat i kar stanowią przychody NFOŚiGW, WFOŚiGW oraz dochody budżetów powiatów i budżetów gmin (por. art. 1 pkt 1 ustawy nowelizującej).

Z dniem 1 stycznia 2010 r. NFOŚiGW stał się państwową osobą prawną w rozumieniu art. 9 pkt 14 ustawy o finansach publicznych ${ }^{20}$. Wskazując normatywną podstawę utworzenia NFOŚiGW, należy zwrócić uwagę nie tylko na treść art. 9 pkt 14 ustawy o finansach publicznych, ale również na treść art. 30 tej ustawy. Państwową osobą prawną może być tylko taka osoba, która została utworzona na podstawie odrębnej ustawy (w tym przypadku ustawy Prawo ochrony środowiska) w celu wykonania zadań publicznych ${ }^{21}$.

Konieczność przekształcenia formy prawnej NFOŚiGW z państwowego funduszu celowego w państwową osobę prawną wynikała z potrzeby dostosowania obecnego systemu finansowania ochrony środowiska i gospodarki wodnej do rozwiązań zawartych w ustawie o finansach publicznych oraz przepisów wprowadzających ustawę o finansach publicznych $^{22}$.

Analogicznie, od dnia 1 stycznia 2010 r., WFOŚiGW, działające jako osoby prawne będące wojewódzkimi funduszami celowymi, stały się sa-

7 Dz.U. Nr 26, poz. 139.

18 Ustawa z dnia 27 kwietnia 2001 r. Prawo ochrony środowiska (tekst jedn. Dz.U. z 2013 r., poz. 1232 ze zm.).

19 Ustawa z dnia 20 listopada 2009 r. o zmianie ustawy - Prawo ochrony środowiska oraz niektórych innych ustaw (Dz.U. Nr 215, poz. 1664).

20 Ustawa z dnia 27 sierpnia 2009 r. o finansach publicznych (tekst jedn. Dz.U. z 2013 r., poz. 885 ze zm.).

21 D. Gajewski, A. Kulon, Finansowanie ochrony środowiska i gospodarki wodnej. Art. 400-421 Prawa ochrony środowiska. Komentarz, Warszawa 2011, s. 46.

22 Tamże, s. 43-44. 
morządowymi osobami prawnymi w rozumieniu art. 9 pkt 14 ustawy o finansach publicznych. WFOŚiGW działają na poziomie wszystkich województw.

W ustawie Prawo ochrony środowiska wskazany został cel i obszar działania NFOŚiGW oraz WFOŚiGW. Fundusze te gromadzą środki publiczne pochodzące w szczególności z opłat za korzystanie ze środowiska oraz administracyjnych kar pieniężnych pobieranych na podstawie ustawy Prawo ochrony środowiska, a także innych opłat i należności pobieranych na podstawie tej ustawy oraz przepisów szczególnych ${ }^{23}$.

Środki finansowe funduszy stanowią m.in. ${ }^{24}$ :

1. opłaty i kary za korzystanie ze środowiska,

2. opłaty eksploatacyjne, koncesyjne i produktowe,

3. administracyjne kary pieniężne,

4. dobrowolne wpłaty,

5. darowizny,

6. świadczenia rzeczowe,

7. środki pochodzące $\mathrm{z}$ fundacji,

8. wpływy z przedsięwzięć organizowanych na rzecz ochrony środowiska i gospodarki wodnej.

Ustawowy katalog celów stanowi szeroką, autonomiczną i jedną regulację, podlegającą zarówno NFOŚiGW, jak i WFOŚiGW. Obejmuje on m.in.:

- $\quad$ przedsięwzięcia związane z ochroną wód, gospodarką wodną oraz zarządzaniem ryzykiem powodziowym,

- $\quad$ przedsięwzięcia związane z gospodarką odpadami,

- $\quad$ przedsięwzięcia związane z ochroną powierzchni ziemi,

- $\quad$ przedsięwzięcia związane z ochroną powietrza,

- $\quad$ wspomaganie wykorzystania lokalnych źródeł energii odnawialnej oraz działalności związanej z wytwarzaniem biokomponentów i biopaliw ciekłych,

23 Tamże, s. 60.

24 J. Jendrośka (red.), Leksykon..., s. 44. 
- $\quad$ przedsięwzięcia związane z ochroną i przywracaniem chronionych gatunków roślin lub zwierząt oraz przedsięwzięcia związane z ochroną przyrody, w tym utrzymanie terenów zielonych, parków,

- $\quad$ przedsięwzięcia z zakresu rolnictwa ekologicznego,

- działania mające na celu zapobieganie lub likwidację poważnych awarii i szkód górniczych oraz ich skutków,

- prowadzenie działalności edukacyjnej w zakresie ekologii.

System finansowania ochrony środowiska poprzez fundusze zyskał międzynarodowe uznanie, w tym Komisji Europejskiej, Organizacji Współpracy Gospodarczej i Rozwoju oraz Banku Światowego ${ }^{25}$.

NFOŚiGW stosuje następujące formy finansowania ${ }^{26}$ :

1. finansowanie zwrotne - czyli pożyczki udzielane przez ten fundusz, kredyty bankowe $\mathrm{z}$ jego środków, konsorcja, linie kredytowe ze środków tego funduszu obsługiwane przez banki;

2. finansowanie dotacyjne - dotacje inwestycyjne i nieinwestycyjne, dopłaty do kredytów bankowych, umorzenia;

3. finansowanie kapitałowe - obejmowanie akcji i udziałów zakładowych bądź już istniejących spółek w celu osiągnięcia efektu ekologicznego.

Zasady finansowania ochrony środowiska przez NFOŚiGW zostały określone w ustawie Prawo ochrony środowiska, jednak podlegają one corocznym doprecyzowaniom poprzez określenie priorytetów finansowania zadań na dany rok. Pozwala to na ukierunkowanie działalności i pomocy finansowej na te obszary, które wymagają szczególnej uwagi oraz nakładów inwestycyjnych ${ }^{27}$.

O przyznaniu NFOŚiGW formy prawno-organizacyjnej określonej jako państwowa osoba prawna przesądziła specyfika zadań publicznych oraz obowiązywanie odrębnej ustawy regulującej problematykę finanso-

25 Materiały źródłowe strony internetowej: http://www.nfosigw.gov.pl (dostęp: 28 października 2013 r.).

26 B. Poskrobko, T. Poskrobko, Zarzqdzanie środowiskiem..., s. 85.

27 P. Gruszecki, Źródła finansowania ochrony środowiska w Polsce, [w:] Raport „Stan środowiska w Polsce w latach 1996-2001”, Warszawa 2003, s. 257, http://www. gios.gov.pl/stansrodowiska/upload/file/pdf/download/raport_2003.pdf (dostęp: 30 października 2013 r.). 
wania ochrony środowiska i gospodarki wodnej. Przyznanie osobowości prawnej stworzyło możliwość realizacji istotnych społecznie zadań. NFOŚiGW można zaliczyć do wiodących instytucji w zakresie finansowania ochrony środowiska w Polsce ${ }^{28}$.

WFOŚiGW mają zbliżone cele statutowej działalności, ale mają mniejszy obszar działania (przede wszystkim przedsięwzięcia na poziomie regionalnym). Fundusze te odgrywają znaczącą rolę $\mathrm{w}$ absorpcji środków pomocowych z Unii Europejskiej.

Do funduszy ochrony środowiska zalicza się także Fundusz Leśny ${ }^{29}$ utworzony na mocy ustawy z dnia 28 września 1991 r. o lasach ${ }^{30}$. Jego dysponentem jest Dyrektor Generalny Państwowego Gospodarstwa Leśnego „Lasy Państwowe”. Do przychodów wskazanego funduszu zalicza się należności:

- z kar i opłat za korzystanie ze środowiska,

- $\quad$ wynikające z odszkodowań cywilnoprawnych za szkody,

- $\quad$ z tytułu przedwczesnego wyrębu drzewostanów na podstawie ustawy

o ochronie gruntów rolnych i leśnych,

- $\quad$ z tytułu odszkodowań za szkody powstałe w wyniku pożarów, prac górniczych i geologicznych,

- $\quad$ z dotacji budżetowych.

Fundusz Leśny gospodaruje środkami finansowymi, przeznaczając je na cele wskazane w ustawie o lasach. Są to głównie: wyrównywanie niedoborów środków finansowych w nadleśnictwie, niedoborów powstających przy realizacji zadań z zakresu gospodarki leśnej, na wspólne przedsięwzięcia jednostek organizacyjnych Lasów Państwowych, na badania naukowe, tworzenie infrastruktury niezbędnej do prowadzenia gospodarki leśnej, sporządzanie planów urządzenia lasu i prognozowanie rozwoju zasobów drzewnych.

Działalność Funduszu Leśnego opiera się na zawieraniu umów pomiędzy Skarbem Państwa - Państwowe Gospodarstwo Leśne Lasy Państwowe a podmiotem, takim jak na przykład Park Narodowy. Umowy na

\footnotetext{
B. Poskrobko, T. Poskrobko, Zarzqdzanie środowiskiem..., s. 82.

A. Lipiński, Prawne podstawy ochrony środowiska, Warszawa 2010, s. 353.

Tekst jedn. Dz.U. z 2011 r. Nr 12, poz. 59 ze zm.
} 
wydatki finansowane ze środków finansowych z Funduszu Leśnego zawierane są na podstawie art. 57 ust. 2 i art. 58 ust. 3 ustawy o lasach.

Do 29 listopada 2010 r. dużą rolę w systemie finansowania ochrony środowiska w Polsce odgrywała Fundacja EkoFundusz, powołana w 1992 r. przez Skarb Państwa, reprezentowanego przez Ministra Finansów. EkoFundusz działał na podstawie ustawy o fundacjach z $1984 \mathrm{r}^{31}$ Jego zadaniem było efektywne zarządzanie środkami pochodzącymi z zamiany części polskiego zadłużenia zagranicznego na finansowanie przedsięwzięć w ochronie środowiska (tzw. ekokonwersja). Swoje należności zredukowały w ten sposób Stany Zjednoczone, Francja, Szwajcaria, Włochy, Szwecja i Norwegia. Ekokonwersja przyczyniła się do przyspieszenia inwestycji ochrony środowiska oraz transferu innowacyjnych technologii w tym zakresie ${ }^{32}$.

Wysokość środków wydatkowanych przez EkoFundusz uzależniona była od wielkości umarzanego długu przez kraje przystępujące do ekokonwersji oraz od wielkości środków budżetowych przeznaczonych na inwestycje w zakresie ochrony środowiska. Warunkiem redukcji zadłużenia było przeznaczenie jej równowartości w walucie polskiej na sfinansowanie działalności służącej ochronie środowiska ${ }^{33}$. Największe wpływy 34,6 mln USD - EkoFundusz odnotował w 2001 roku. Natomiast największy udział w wydatkach z EkoFunduszu miały inwestycje związane z ochroną Bałtyku ${ }^{34}$.

\subsection{Działalność BOŚ w zakresie kredytowania przedsięwzięć z zakresu ochrony środowiska}

Ważną częścią działalności BOŚ jest wspieranie działań na rzecz ochrony środowiska. Dużą rolę przy tworzeniu BOŚ odegrał NFOŚiGW, który był

\footnotetext{
Tekst jedn. Dz.U. z 1991 r. Nr 46, poz. 203 ze zm.

32 Materiały źródłowe na stronie internetowej http://www.ekofundusz.org.pl (dostęp: 28 października 2013 r.).

33 B. Karlikowska, Źródła finansowania inwestycji proekologicznych w Polsce, [w:] Ekonomiczno-finansowe i prawne instrumenty..., s. 66.

34 P. Gruszecki, Źródła..., s. 258.
} 
pierwszym akcjonariuszem banku, a obecnie pozostaje akcjonariuszem strategicznym.

Obecnie BOŚ prowadzi tzw. politykę środowiskową, która oznacza respektowanie prawa w zakresie ochrony środowiska, racjonalizację w zakresie zużycia wody, energii elektrycznej, ciepła i paliw, gospodarowanie odpadami oraz popularyzację wiedzy na temat proekologicznych rozwiązań $^{35}$.

BOŚ posiada w swojej strukturze organizacyjnej Departament Projektów Ekologicznych. Związane jest to z prowadzeniem przez bank dynamicznej polityki kredytowej na rzecz inwestycji proekologicznych. BOŚ udziela kredytów we współpracy z NFOŚiGW oraz we współpracy z WFOŚiGW.

W swojej ofercie komercyjnej BOŚ proponuje kredyty proekologiczne, a wśród nich ${ }^{36}$ :

- $\quad$ kredyt Dom EnergoOszczędny,

- słoneczny EkoKredyt,

- $\quad$ kredyt z Dobrą Energią,

- kredyt na urządzenia i wyroby służące ochronie środowiska,

- $\quad$ kredyt EkoMontaż,

- $\quad$ kredyt EnergoOszczędny,

- $\quad$ kredyt EkoOszczędny,

- $\quad$ kredyt z Klimatem,

- $\quad$ ekologiczne kredyty hipoteczne,

- $\quad$ kredyty we współpracy z WFOŚiGW (oferta jest zróżnicowana i zależy od województwa, w którym realizowana jest kredytowana inwestycja).

Kredyty powyższe skierowane są do szerokiego grona potencjalnych odbiorców. Wśród nich wyróżnia się m.in.: jednostki samorządu terytorialnego, spółki komunalne, duże, małe i średnie przedsiębiorstwa, wspólnoty mieszkaniowe, klientów indywidualnych, spółdzielnie mieszkaniowe, spółki prawa handlowego.

35 Materiały źródłowe na stronie internetowej http://www.bosbank.pl (dostęp: 1 listopada 2013 r.).

36 Tamże. 
Przedstawiając ofertę BOŚ w zakresie finansowania ochrony środowiska, można dokonać podziału na:

1. kredyty proekologiczne preferencyjne,

2. kredyty proekologiczne komercyjne,

3. kredyty ze środków banków zagranicznych (np. Europejskiego Banku Inwestycyjnego),

4. emisje obligacji komunalnych.

\subsection{Działalność banków komercyjnych w zakresie kredytowania ochrony środowiska}

Miernikiem roli sektora bankowego w systemie finansowania ochrony środowiska jest wartość udzielanych kredytów wypłaconych i ich udział w łącznej kwocie nakładów na ochronę środowiska. Należy mieć na uwadze, że kredyty są zwrotnym źródłem finansowania. Na zadania z zakresu ochrony środowiska przedsiębiorcy bądź osoby fizyczne mogą uzyskać środki z banków w ramach ${ }^{37}$ :

- ogólnych linii kredytów inwestycyjnych na warunkach komercyjnych,

- $\quad$ specjalnych linii kredytowych na sfinansowanie zadań proekologicznych na zasadach komercyjnych,

- $\quad$ kredytów preferencyjnych.

Banki komercyjne w zakresie swojej działalności mogą udzielać kredytów zarówno przedsiębiorcom prowadzącym działalność gospodarczą, jak i osobom fizycznym. Obok kredytów również pożyczki bankowe były ważnym źródłem finansowania ochrony środowiska w Polsce w okresie przedakcesyjnym, czyli do 2004 r. Zmniejszenie roli tego źródła finansowania spowodowane było wzrostem zainteresowania innymi środkami, głównie unijnymi.

Z kredytów banków komercyjnych, jako środków finansujących zadania z zakresu ochrony środowiska, korzysta określona grupa odbiorców. Zasady zawierania umów kredytu bankowego określone zostały w ustawie

\footnotetext{
B. Poskrobko, J. Ejdas, System finansowania ochrony..., s. 121.
} 
z dnia 29 sierpnia 1997 r. Prawo bankowe ${ }^{38}$ lub w innych ustawach oraz w regulaminach bankowych. Cechami umowy kredytu są: jej kwalifikowany charakter, pieniężność, odpłatność, celowość kredytu oraz jego zwrotność $^{39}$. Umowa kredytowa jest umową konsensualną, dwustronnie zobowiązującą oraz odpłatną ${ }^{40}$.

Pożyczka pieniężna nie jest typową czynnością bankową, ponieważ może być udzielana nie tylko przez banki. W ustawie Prawo bankowe zawarto nieliczne postanowienia odnoszące się do udzielania bankowych pożyczek pieniężnych. Do procedur udzielania pożyczek i oceny zdolności płatniczej pożyczkobiorcy analogicznie stosuje się przepisy regulujące działalność kredytową ${ }^{41}$.

Należy także zwrócić uwagę, iż inwestycje z zakresu ochrony środowiska mogą być finansowane jednocześnie z kredytu bankowego i z innego źródła (środków funduszowych lub zagranicznych). Każda sytuacja zaciągania kredytu przez przedsiębiorcę lub osobę fizyczną na cel, określany ogólnie jako ochrona środowiska, jest indywidualnie rozpatrywana.

Banki komercyjne oferują kredyty na przedsięwzięcia ochronne z funduszy własnych banku, ze środków powierzonych lub z funduszy własnych banku z dopłatą do oprocentowania ze środków zewnętrznych.

\subsection{Rola BGK we wspieraniu przedsięwzięć z zakresu ochrony środowiska}

BGK pełni obecnie szczególną pozycję na rynku usług bankowych. Uczestniczy on aktywnie w realizacji gospodarczych zadań państwa, zarządza środkami funduszy oraz programami rządowymi; stanowi także ważne ogniwo w zakresie finansowania przedsięwzięć z zakresu ochrony środowiska, w tym rynku oszczędności energii. Jest on dysponentem

Tekst jedn. Dz.U. z 2012 r., poz. 1376 ze zm.

Z. Ofiarski, Prawo bankowe, Warszawa 2011, s. 191.

40 M. Ziembiński, Jak uzyskać kredyt lub gwarancję bankowq?, „Monitor Podatkowy” 1994, nr 3, s. 89.

41 Z. Ofiarski, Prawo..., s. 260-262. 
środków Komisji Europejskiej oraz środków Europejskiego Banku Odbudowy i Rozwoju ${ }^{42}$.

BGK administruje powierzonymi na podstawie odrębnych ustaw funduszami, które wspierają poszczególne dziedziny życia gospodarczego i podejmowane są w ramach tego działania na rzecz ochrony środowiska. Jako przykład podać można Fundusz Żeglugi Śródlądowej, który w strukturach BGK funkcjonuje od 2003 r. Celem tego funduszu jest udzielanie wsparcia finansowego na restrukturyzację sektora żeglugi śródlądowej, w tym przedsięwzięć mających na celu poprawę ochrony środowiska. Formą wsparcia jest udzielanie kredytów preferencyjnych, kredytów uzupełniających w formie dopłat do kredytów komercyjnych i ich umorzeń ${ }^{43}$.

\section{Rola i znaczenie środków zagranicznych jako źródeł finansowania ochrony środowiska}

Przystąpienie Polski do UE w 2004 r., przyniosło ważne zmiany w zakresie finansowania zadań z zakresu ochrony środowiska. Jednolita polityka objęła również tę dziedzinę życia społeczno-gospodarczego, która dotyczyła ochrony środowiska. Zapoczątkowało to ożywiony okres w zakresie wspierania i rozwoju przedsięwzięć w zakresie ochrony środowiska w różnych jej obszarach.

W 2004 r. prawie połowa środków unijnych dla nowych państw członkowskich trafiła do polskich beneficjentów, przede wszystkim samorządów i innych podmiotów publicznych. Wartość środków z UE na ochronę środowiska w Polsce w latach 2004-2006 wyniosła ok. 2,5 mld euro $^{44}$.

Inwestycje w okresie 2004-2006 finansowane były z unijnego budżetu w ramach funduszy strukturalnych, Funduszu Spójności oraz in-

42 Materiały źródłowe na stronie internetowej http://www.sejm.gov.pl (dostęp: 10 grudnia 2013 r.)

43 Materiały źródłowe na stronie internetowej http://www.bgk.com.pl (dostęp: 29 października 2013 r.).

44 J. Karpińska, Finansowanie ochrony środowiska w Polsce ze źródeł europejskich w aspekcie okresu programowania 2007-2013, ,Zeszyty Naukowe SGGW w Warszawie - Problemy Rolnictwa Światowego”, t. 2(17), s. 342. 
strumentu finansowego na rzecz ochrony środowiska LIFE. Do funduszy strukturalnych wówczas zaliczały się: Europejski Fundusz Rozwoju Regionalnego, Europejski Fundusz Społeczny, Europejski Fundusz Orientacji i Gwarancji Rolnych (sekcja „Orientacja”), Finansowy Instrument Orientacji Rybołówstwa. Projekty dotyczące ochrony środowiska mogły uzyskać także wsparcie w ramach Mechanizmu Finansowego Europejskiego Obszaru Gospodarczego i Norweskiego Mechanizmu Finansowego 45 .

Środki finansowe przekazywane przez UE są obecnie jednym z podstawowych źródeł finansowania inwestycji ekologicznych w Polsce. Źródłem finansowania przedsięwzięć na ochronę środowiska w latach 2007-2013 jest kończący się już Program Operacyjny Infrastruktura i Środowisko (dalej: POIiŚ) ${ }^{46}$. Środki unijne na POIiŚ pochodzą z dwóch źródeł: z Funduszu Spójności oraz Europejskiego Funduszu Rozwoju Regionalnego. Największe wsparcie w ramach tego projektu otrzymał transport, na drugim miejscu - szeroko rozumiane środowisko. Wartość środków unijnych przeznaczonych na ochronę środowiska w Polsce w latach 20072013 wyniesie ponad 5 mld euro ${ }^{47}$.

Finansowanie (głównie dofinansowywanie) z POIiŚ środowiska obejmuje głównie inwestycje komunalne, ekologiczne w przedsiębiorstwach, projekty ochrony przyrody, bezpieczeństwo ekologiczne, a także edukację ekologiczną. Na wsparcie z tego programu liczyć mogły samorządy, przedsiębiorcy i organizacje pozarządowe, Lasy Państwowe i parki narodowe ${ }^{48}$.

45 Materiały źródłowe na stronie internetowej http://www.funduszeeuropejskie.pl (dostęp: 30 października 2013 r.).

46 Program Operacyjny Infrastruktura i Środowisko jest instrumentem realizacji odnowionej Strategii Lizbońskiej, natomiast wydatki na cele priorytetowe UE spełniające kryteria określone w art. 9 ust. 3 rozporządzenia nr 1083/2006 ustanawiającego przepisy ogólne dotyczące Europejskiego Funduszu Rozwoju Regionalnego, Europejskiego Funduszu Społecznego oraz Funduszu Spójności i uchylającego rozporządzenie WE nr 1260/1999 (Dz.Urz. UE L 2006, Nr 210, s. 25.).

47 Materiały źródłowe na stronie internetowej http://www.pois.gov.pl (dostęp: 28 października 2013 r.).

48 J. Karpińska, Finansowanie..., s. 345. 
W ramach POIiŚ realizowanych jest pięć priorytetów środowiskowych $^{49}$ :

- gospodarka wodno-ściekowa,

- gospodarka odpadami i ochrona powierzchni ziemi,

- bezpieczeństwo ekologiczne,

- przedsięwzięcia dostosowujące przedsiębiorstwa do wymogów ochrony środowiska,

- ochrona przyrody i kształtowania postaw ekologicznych.

W ramach środków udostępnianych z Regionalnych Programów Operacyjnych wsparciem mogą być objęte jednostki samorządu terytorialnego i ich jednostki organizacyjne, związki, porozumienia i stowarzyszenia jednostek samorządu terytorialnego, inne instytucje sektora publicznego, organizacje pozarządowe, partnerstwa publiczno-prawne, jednostki organizacyjne Lasy Państwowe, przedsiębiorcy.

W latach 2007-2013 celem wsparcia finansowego utworzono instrument LIFE+, będący naturalną kontynuacją wcześniejszego instrumentu LIFE. Jego zadanie sprowadzone zostało do współfinansowaniu projektów z zakresu ochrony środowiska, a za cel postawiono wspieranie procesu wdrażania wspólnotowego prawa ochrony środowiska, realizację polityki ochrony środowiska oraz identyfikację i promocję nowych rozwiązań dla problemów dotyczących ochrony środowiska ${ }^{50}$.

W okresie funkcjonowania instrumentu LIFE wnioski o przyznanie środków i ich ocena dokonywane były bezpośrednio przez Komisję Europejską. Od 2007 r. zasady te uległy uproszczeniu. W ramach instrumentu LIFE+ określone zostały pule środków dla każdego państwa członkowskiego. Projekty są składane i oceniane na poziomie krajowym.

Do pozostałych funduszy unijnych, w ramach których możliwe jest finansowanie przedsięwzięć z zakresu ochrony środowiska, należą Fundusz Spójności i Fundusze Strukturalne (Europejski Fundusz Rozwoju Regionalnego, Europejski Fundusz Społeczny, Europejski Fundusz Orien-

49 Materiały źródłowe na stronie internetowej http://www.pois.gov.pl (dostęp: 28 października 2013 r.).

50 Materiały źródłowe na stronie internetowej NFOŚiGW http://www.nfosigw.gov.pl (dostęp: 10 grudnia 2013 r.). 
tacji i Gwarancji Rolnej, Europejski Instrument Sterowania Rybołówstwem).

Fundusze europejskie będą wspierały rozwój gospodarczy w Polsce także w następnych latach. Rada Europejska podjęła kluczowe decyzje w sprawie budżetu unijnego na lata 2014-2020. Po zatwierdzeniu ich przez Parlament Europejski Polska otrzyma 72,9 mld euro na realizację polityki spójności. Środki te będzie można zadysponować m.in. na „zieloną” energię oraz transport przyjazny środowisku. W ramach podziału tych funduszy na programy krajowe projekt Infrastruktura i środowisko ma otrzymać 24158 mld euro ${ }^{51}$.

Innym zagranicznym źródłem finansowania ochrony środowiska jest bezzwrotna pomoc pod nazwą: Mechanizm Finansowy EOG oraz Norweski Mechanizm Finansowy (potocznie znanych i nazywanych funduszami norweskimi). Pochodzą one z trzech krajów Europejskiego Stowarzyszenia Wolnego Handlu, będących jednocześnie członkami Europejskiego Obszaru Gospodarczego - Norwegii, Islandii i Lichtensteinu ${ }^{52}$.

We wcześniejszych latach, głównie 1991-2001, jednym z ważniejszych źródeł zagranicznych finansowania zadań z zakresu ochrony środowiska były programy PHARE i ISPA oraz instrument rolny SAPARD. Wielkość dotacji z tych programów wynosiła 75,8\% wszystkich dotacji przyznanych Polsce w ramach pomocy zagranicznej w latach 1991-2001. Środki wówczas pozyskane przeznaczono głównie na ochronę wód i podejmowanie działań w gospodarce wodnej ${ }^{53}$.

W okresie przedakcesyjnym środki ISPA i SAPARD w całości, natomiast PHARE w znacznej części, wykorzystywane były na realizację priorytetów zawartych we Wstępnym narodowym Planie Rozwoju, który

51 Materiały źródłowe na stronie internetowej Ministerstwa Rozwoju Regionalnego http://www.mrr.gov.pl (dostęp: 1 listopada 2013 r.); od 27 listopada 2013 r. funkcje MRR przejęło Ministerstwo Infrastruktury i Rozwoju (http://www.mir.gov.pl).

52 Materiały źródłowe na stronie internetowej NFOŚiGW http://www.nfosigw.gov.pl (dostęp: 28 października 2013 r.).

53 Materiały źródłowe na stronie internetowej Ministerstwa Gospodarki http://www.mg. gov.pl (dostęp: 10 grudnia 2013 r.). 
uważany był za dokument strategiczny dla prowadzenia polityki spójności gospodarczej, ze szczególnym uwzględnieniem ochrony środowiska ${ }^{54}$.

Wskazując na zagraniczne źródła finansowania zadań z zakresu ochrony środowiska w Polsce, należy wspomnieć o roli Banku Światowego, którego jednym z założycieli była Polska. Bank Światowy zapewnia pomoc techniczną i doradztwo w zakresie polityki oraz pomoc finansową, której zadaniem jest wspieranie rozwoju gospodarki rynkowej oraz stymulowanie stałego wzrostu gospodarczego. Do obszarów współpracy Banku Światowego i Polski należy m.in. osiąganie celów w zakresie ochrony środowiska. Bank Światowy odegrał szczególną rolę podczas przygotowań Polski do członkowstwa w UE.

\section{Konkluzje}

Środki finansowe niezbędne do realizacji zadań z zakresu ochrony środowiska powinny pochodzić z różnych źródeł. Należy do nich zaliczyć także wydatki ponoszone przez podmioty korzystające ze środowiska lub oddziaływujące na nie (np. zakłady przemysłowe, osoby fizyczne), a w szczególności opłaty za dostawę wody, odprowadzanie ścieków, odbieranie odpadów komunalnych. Do tych wydatków należałoby dodać także opłaty wliczone w cenę niektórych produktów konsumpcyjnych.

Zgodnie z zasadą „zanieczyszczający płaci” większość środków finansowych powinna pochodzić od korzystających ze środowiska bądź oddziaływujących na nie. Nie może to jednak oznaczać zwolnienia organów administracji publicznej z obowiązku pozyskiwania i udzielania wszelkich form wsparcia finansowego na zadania, których celem jest ochrona środowiska w szerokim zakresie.

Opierając się na założeniu, że środowisko jest dobrem narodowym oraz że jego kondycją powinni być zainteresowani wszyscy uczestnicy procesu gospodarowania, ochrona środowiska nabrała w ostatnich latach charakteru społecznego. Stanowi to gwarancję dbałości o środowisko

54 A. Barczak, Europejska pomoc ekologiczna dla Polski i państw członkowskich (analiza prawnoporównawcza), „Zeszyty Naukowe Wyższej Szkoły Morskiej w Szczecinie” 2001, nr 63, s. 32. 
w sposób ciągły. Charakter społeczny oznacza przejęcie części odpowiedzialności za ochronę środowiska przez podmioty prywatne (np. przedsiębiorców, osoby fizyczne). Styl życia, wiedza na temat ochrony środowiska i zdrowego żywienia oraz edukacja ekologiczna przyczyniły się bez wątpienia do wzrostu tej odpowiedzialności, co w dużej mierze przekłada się na odpowiedzialność finansową. Jednakże kompleksowa działalność finansowa na rzecz ochrony środowiska jest niemożliwa bez wsparcia państwa i samorządu terytorialnego.

Po akcesji Polski do UE rozszerzyła się możliwość wykorzystania dodatkowych funduszy na realizację zadań z zakresu ochrony środowiska. Środki z budżetu unijnego stały się głównym impulsem do podejmowania działań na płaszczyźnie ochrony środowiska oraz skłoniły dodatkowo do wydatkowania środków krajowych i uruchamiania funduszy własnych przedsiębiorców na inwestycje w tym zakresie.

Znaczącym bodźcem, głównie na poziomie centralnym i samorządowym, stymulującym wydatki na ochronę środowiska w Polsce jest wymóg wywiązania się z przyjętych zobowiązań w Traktacie Akcesyjnym.

\section{Bibliografia:}

Barczak A., Europejska pomoc ekologiczna dla Polski i państw członkowskich (analiza prawnoporównawcza), „Zeszyty Naukowe Wyższej Szkoły Morskiej w Szczecinie” 2001, nr 63, s. 29-37.

Ciechanowicz-McLean J., Fundusze Ochrony Środowiska i Gospodarki Wodnej [w:] J. Ciechanowicz-McLean (red.), Leksykon ochrony środowiska, C.H. Beck, Warszawa 2009.

Ciechanowicz-McLean J., Bukowski Z., Rakoczy B., Prawo ochrony środowiska. Komentarz, LexisNexis, Warszawa 2008.

Gajewski D., Kulon A., Finansowanie ochrony środowiska i gospodarki wodnej. Art. 400-421 Prawa ochrony środowiska. Komentarz, C.H. Beck, Warszawa 2011.

Gruszecki P., Źródła finansowania ochrony środowiska w Polsce, [w:] Raport „Stan środowiska w Polsce w latach 1996-2001”, Inspekcja Ochrony Środowiska, Warszawa 2003. 
Jendrośka J. [red.], Leksykon prawa ochrony środowiska, Wolters Kluwer, Warszawa 2012.

Karlikowska B., Źródła finansowania inwestycji proekologicznych w Polsce [w:] J. Zalewa (red.), Ekonomiczno-finansowe i prawne instrumenty ochrony środowiska naturalnego w Polsce, Wydawnictwo Uniwersytetu Marii Curie-Skłodowskiej, Lublin 2001.

Karpińska J., Finansowanie ochrony środowiska w Polsce ze źródeł europejskich w aspekcie okresu programowania 2007-2013, „Zeszyty Naukowe SGGW w Warszawie - Problemy Rolnictwa Światowego”, t. 2(17), s. 342-351.

Kozłowska B. [red.], Instrumenty polityki ekologicznej, Polska Akademia Nauk, Oddział w Łodzi, Łódź 2005.

Lipiński A., Prawne podstawy ochrony środowiska, Wolters Kluwer, Warszawa 2010.

Ofiarski Z., Prawo bankowe, Wolters Kluwer, Warszawa 2011, s. 191.

Poskrobko B., Poskrobko T., Zarzqdzanie środowiskiem w Polsce, Polskie Wydawnictwo Ekonomiczne, Warszawa 2012.

Poskrobko B., Zarzq̨dzanie środowiskiem, Polskie Wydawnictwo Ekonomiczne, Warszawa 1999.

Smoleń P., Fundusze ochrony środowiska i gospodarki wodnej, [w:] J. Stelmasiak (red.), Prawo ochrony środowiska, LexisNexis, Warszawa 2009.

Urban S., Finansowanie ochrony środowiska i gospodarki wodnej, [w:] M. Górski, M. Pchałek, W. Radecki, J. Jerzmański, M. Bar, S. Urban, J. Jendrośka, Prawo ochrony środowiska. Komentarz, C.H. Beck Warszawa 2011.

Wyzińska-Ludian J., Źródła finansowania ekorozwoju, [w:] J. Zalewa (red.), Ekonomiczno-finansowe i prawne instrumenty ochrony środowiska naturalnego w Polsce, Wydawnictwo Uniwersytetu Marii Curie-Skłodowskiej, Lublin 2001.

Ziembiński Z., Jak uzyskać kredyt lub gwarancję bankową?, „Monitor Podatkowy” 1994, nr 3, s. 78-89. 